\title{
Association between Three Variants in the PRKAA2 gene, rs2796498, rs9803799, and rs2746342, with 10-year ASCVD Risk on Newly Diagnosed T2DM in Yogyakarta, Indonesia
}

\author{
Dita Maria Virginia ${ }^{1,2} \mathbb{D}$, Mae Sri Hartati Wahyuningsih ${ }^{1} \mathbb{D}$, Dwi Aris Agung Nugrahaningsih ${ }^{1,3 *}$ (D) \\ ${ }^{1}$ Department of Pharmacology and Therapy, Faculty of Medicine, Public Health and Nursing, Universitas Gadjah Mada, \\ Yogyakarta, Indonesia; ${ }^{2}$ Faculty of Pharmacy, Sanata Dharma University, Yogyakarta, Indonesia; ${ }^{3}$ Center of Genetic Study, \\ Faculty of Medicine, Public Health and Nursing, Universitas Gadjah Mada, Yogyakarta, Indonesia
}

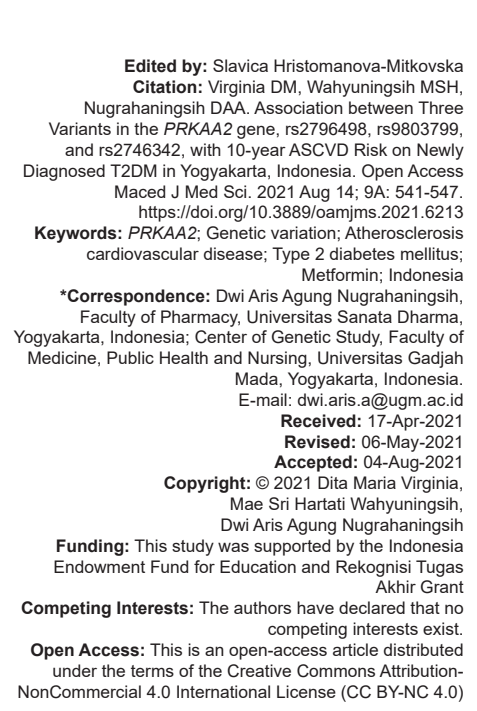

\section{Introduction}

AMPK is an energy sensor and maintains homeostasis so it has an important role in glucose and lipid metabolism. AMPK consists of three subunits $(\alpha, \beta$, and $\gamma$ ). Phosphorylated AMPK in Thr172 in the $\alpha$ subunit has the primary function to induce AMPK downstream activation [1]. Accordingly, AMPK is the target of the mechanism of action of metformin. Metformin is an oral antidiabetic agent with a mechanism as an insulin sensitizer and reduces gluconeogenesis by AMPK activation [2], [3]. A study in mice showed that AMPK $\alpha 2$ knockout had higher glucose levels and lower insulin concentration during meals and insulin resistance compared to wild type [4]. AMPK $\alpha 2$, which is encoded by PRKAA2, is one of the pharmacogenetic research targets, especially in metformin pharmacodynamic research. AMPK $\alpha 2$ is dominant in muscles and the liver [5], [6]. AMPK $\alpha 2$ was involved in reducing left ventricle pressure and smooth muscle relaxation [7], [8]. Therefore, it might contribute to lowering atherosclerosis cardiovascular disease (ASCVD) risk.

In fact, ASCVD causes the highest mortality and morbidity among diabetic patients, especially in type 2 diabetes mellitus (T2DM). Consequently, ASCVD is considered in T2DM therapy management [9]. Patients with T2DM have a 2-4 fold higher possibility of developing ASCVD risk, although this risk is not equal among individuals because of the heterogeneity in the population [10]. The increased risk of ASCVD mortality is associated with younger age groups, poor glycemic control, and increased renal complications [11]. In addition, patients with newly diagnosed T2DM tend to have higher poor glycemic control [12].

Pathogenesis of ASCVD and T2DM is related to epigenetic, genetic, and cell signaling interference, 
which is correlated with inflammatory and metabolic pathways [13]. High glucose levels elevate advanced glycosylation end products (AGEs) formation. AGEs deposition increases fibrosis, cardiac stiffness, and inhibits diastolic relaxation. AGEs are associated with macrophages function resulting in escalating ASCVD risk [14], [15]. Insulin resistance could increase blood lipid levels, and systemic inflammation markers including, C-reactive protein, interleukin 6, and amyloid A which could predict ASCVD complications among patients with T2DM [16].

Several ASCVD risk calculators are freely available, including the Framingham risk score, SCORE, and pooled-cohort equation (PCE). The PCE was reported to be able to estimate ASCVD risk better when the racial difference was found [17]. A previous study in Sleman showed that there was no significant difference in the results of ASCVD risk calculated using SCORE or PCE [18].

Metformin is the first choice recommended by international guidelines [9], [19]. A previous study in newly diagnosed T2DM patients in the Asian population showed that metformin could control $\mathrm{HbA} 1 \mathrm{c}$ after 3 months [20]. The effect of metformin reducing ASCVD risk in patients with T2DM remains controversial. A previous meta-analysis study reported that metformin did not show a protective effect on ASCVD risk [21]. On the other hand, a review stated that metformin could reduce ASCVD risk effectively [22]. Recent research determined that genetic variation affects metformin efficacy, but it still requires clinical research to confirm these findings [23].

However, the effect of genetic variation in AMPK $\alpha 2$, encoded by PRKAA2, has not been discovered yet related to ASCVD risk. Accordingly, this recent study aimed to examine the association of PRKAA2 genetic variation and ASCVD risk among newly diagnosed T2DM patients who receive monotherapy metformin.

\section{Methods}

\section{Study designs and participants}

A casecontrol study was conducted among newly diagnosed T2DM patients who receiving monotherapy metformin from ten primary health care centers in the Sleman District of Daerah Istimewa Yogyakarta, Indonesia. A total of 107 participants were examined who were required to fast at least 10 hours for clinical laboratory measurements. In this study, the inclusion criteria were: adult participants who were aged 40-70 years old, newly diagnosed T2DM with monotherapy metformin, and without previous ASCVD history. The exclusion criteria were: patients who did not fulfill PEC requirements as outlined in the following conditions. Using the PEC calculation requirements were: systolic blood pressure $90-200 \mathrm{mmHg}$, diastolic blood pressure $60-130 \mathrm{mmHg}$, total cholesterol 130-320 mg/dL, HDL-c 20-100 mg/dL, and LDL-c 30-300 $\mathrm{mg} / \mathrm{dL}$. The high ASCVD risk (> 5\%) was categorized as the case group, and the low ASCVD risk $(<5 \%)$ was categorized as the control group.

Written informed consent was obtained and signed by all participants. The protocol of the study was reviewed and approved by the Medical and Health Research Ethics Committee (MHREC) Faculty of Medicine, Public Health, and Nursing Universitas Gadjah Mada - Dr. Sardjito General Hospital (KE/FK/0633/EC/2019).

\section{Anthropometric examination, clinical laboratory measurements and ASCVD score calculation}

Anthropometric measurements including weight, height, and waist circumference were conducted by a nutritionist. Blood pressure was measured by well-trained nurses. Age, gender, family history of diabetes, smoking status, meal routine, and physical activity intensity were collected by a questionnaire. Hypertension therapy, statin user, and aspirin consumption were obtained from interviews and then were confirmed through medical records.

A professional analyst collected a blood sample after overnight fasting, lasting approximately 10-12 h. Prodia did all clinical laboratory examinations as an accredited laboratory. Fasting blood glucose was measured using the hexokinase method, and $\mathrm{HbA1c}$ was assessed using high-performance liquid chromatography D-10. T2DM patients were defined by $\mathrm{HbA} 1 \mathrm{c}>6.5 \%$. Lipid profiles, including total cholesterol, triglycerides, and high-density lipoprotein cholesterol (HDL-c), were assayed using Cobas C-311. Lowdensity lipoprotein cholesterol (LDL-C) was calculated using the Friedewald equation (total cholesterol HDL-c - Triglycerides/5 in mg/dL, but triglycerides should be $<400 \mathrm{mg} / \mathrm{dL}$ ). Blood pressure $>140 />90 \mathrm{mmHg}$ was classified as hypertension. This study adopted the formulation developed by ACC/AHA pooled cohort equation (http://tools.acc.org/ASCVD-Risk-EstimatorPlus/\#!/calculate/estimate/) to calculate the 10-year ASCVD risk score [24]. The 10-year ASCVD risk score $<5 \%$ was defined as the low-risk (control) group and the risk score $>5 \%$ was defined as the high-risk (case) group.

\section{DNA isolation and PRKAA2 genotyping analysis}

DNA was isolated from blood samples which was done by adding EDTA using the Geneaid ${ }^{\circledR}$ Blood DNA Mini Kit and deposited at $-20^{\circ} \mathrm{C}$ until the genotyping procedure. Genotyping was performed 
using the $\operatorname{TaqMan}^{\circledR}$ genotyping assay and Applied Biosystems ${ }^{\circledR}$ qPCR 7500 Fast Real-Time PCR System to identify rs2796498, rs9803799, and rs2746342. Genotype identification of rs2796498, rs9803799, and rs2746342 was performed using specifically designed TaqMan primer sequences as follows:

rs2796498: CTGTAACAGTGTTAGTGATTTAA AC[A/G]GAGAGAGCAACCTTACCCTTTCAGT

rs9803799: TAAATACAGGGTTTATATCCCCA CA[G/T]TCAATGTAAATTCCTTTTTTTAAAA

\section{rs2746342: AGAGAGGCTAAGATGCAGGCT GTAC[G/T]CTGGGTAGCCATGTACTCAGTTGTA}

The total volume of amplification mixture used in the real-time PCR was $10 \mathrm{~mL}$, including $5 \mathrm{~mL}$ TaqMan GTXpress mix, $2.5 \mathrm{~mL}$ nucleotide-free water, and a $0.5 \mathrm{~mL}$ TaqMan SNP genotyping assay, and $2 \mathrm{~mL}$ of genomic DNA sample. The amplicons were set up according to the following program: fourty cycles at hold $95^{\circ} \mathrm{C}$ for the $20 \mathrm{~s}$, at denaturing $95^{\circ} \mathrm{C}$ for $3 \mathrm{~s}$, and then annealing $60^{\circ} \mathrm{C}$ for $30 \mathrm{~s}$.

\section{Statistical analysis}

We stratified these data by ASCVD risk category and then analyzed the differences using independent t-tests for numeric variables and chisquared tests for categorical variables. We involved the dominant and recessive models in detecting an association with 10-year ASCVD risk. The association between the three studied variants and 10-year ASCVD risk was analyzed using logistic regression analysis. Confounder variables, including sex, age, HDL-c, total cholesterol, triglycerides, high-intensity physical activity, the routine of lunch, dinner, and snack that had a significant association to 10-year ASCVD risk were introduced into multivariate analysis. All statistical analysis were performed using SPSS version 25.0 , and $p<0.05$ was adopted as statistically significant.

\section{Results}

Of the 107 participants who were newly diagnosed with T2DM and only received monotherapy metformin for three months, 16 were excluded because they did not fulfill PCE requirements. For our sample of 91 participants, the average age was $54.40 \pm 7.75$ years old, $74.7 \%$ were female, BMI and waist circumference tended toward overweight status, mean blood pressure was in the pre-hypertension category, the mean of $\mathrm{HbA} 1 \mathrm{c}$ level was $8.35 \pm 1.31 \%$, and lipid profile was in the normal conditions. Only $36.3 \%$ of participants had a family history of T2DM, and only $16.5 \%$ were active or former smokers. High ASCVD risk as the case group had 34 patients and low ASCVD risk as the control group had 57 patients.

Moreover, we compared the participant's characteristics according to ASCVD risk classification. We found age, HbA1c level, sex, and smoking status were significantly different between those two groups $(p<0.05)$. The high-risk group tended to have older participants than the low-risk group $(p<0.01)$. Notably, the $\mathrm{HbA} 1 \mathrm{c}$ level was higher in the low-risk group (8.57 $\pm 1.40 \%)$ than the high-risk group $(7.99 \pm 1.06 \%)$ $(p=0.04)$. Female patients were found more common in the low-risk $(94.7 \%)$ than high-risk group $(41.2 \%)$ $(p<0.01)$. Smoking status was found higher significantly $(p<0.01)$ in the high-risk group $(38.2 \%)$ than in the low-risk group (3.5\%). Demographic characteristics are presented in Table 1.

Table 1: Characteristics of participants with different 10-year ASCVD risk

\begin{tabular}{|c|c|c|c|c|}
\hline \multirow[t]{2}{*}{ Variable } & \multicolumn{4}{|c|}{ Newly diagnosed T2DM patients using monotherapy metformin } \\
\hline & Total $(n=91)$ & Low-risk $(n=57)$ & High-risk $(n=34)$ & p-value \\
\hline Age (years old) & $54.40 \pm 7.75$ & $50.98 \pm 6.20$ & $60.12 \pm 6.70$ & $0.00 * *$ \\
\hline $\mathrm{BMI}\left(\mathrm{kg} / \mathrm{m}^{2}\right)$ & $25.05 \pm 3.96$ & $25.47 \pm 4.26$ & $24.35 \pm 3.33$ & 0.19 \\
\hline Waist circumference $(\mathrm{cm})$ & $87.23 \pm 8.66$ & $87.67 \pm 8.44$ & $86.50 \pm 9.09$ & 0.54 \\
\hline $\begin{array}{l}\text { Systolic blood pressure } \\
(\mathrm{mmHg})\end{array}$ & $125.73 \pm 11.19$ & $124.82 \pm 11.90$ & $127.24 \pm 9.87$ & 0.32 \\
\hline $\begin{array}{l}\text { Diastolic blood pressure } \\
(\mathrm{mmHg})\end{array}$ & $80.70 \pm 6.95$ & $79.68 \pm 6.26$ & $82.41 \pm 7.77$ & 0.09 \\
\hline HbA1c (\%) & $8.35 \pm 1.31$ & $8.57 \pm 1.40$ & $7.99 \pm 1.06$ & $0.04 *$ \\
\hline $\begin{array}{l}\text { Fasting blood glucose } \\
\text { (mg/dL) }\end{array}$ & $136.95 \pm 29.99$ & $137.02 \pm 29.44$ & $136.82 \pm 31.36$ & 0.98 \\
\hline Total cholesterol (mg/dL) & $184.70 \pm 27.23$ & $182.16 \pm 26.21$ & $188.97 \pm 28.60$ & 0.25 \\
\hline Triglyceride (mg/dL) & $138.05 \pm 57.68$ & $133.70 \pm 59.76$ & $145.35 \pm 54.10$ & 0.35 \\
\hline HDL-c (mg/dL) & $47.48 \pm 8.34$ & $48.61 \pm 8.11$ & $45.59 \pm 8.51$ & 0.09 \\
\hline LDL-c (mg/dL) & $109.58 \pm 22.02$ & $106.77 \pm 21.13$ & $114.29 \pm 22.98$ & 0.12 \\
\hline Sex, female & $68(74.7)$ & $54(94.7)$ & $14(41.2)$ & $0.00 * *$ \\
\hline $\begin{array}{l}\text { Family history of } \\
\text { diabetes, yes }\end{array}$ & $33(36.3)$ & $22(38.6)$ & $11(32.4)$ & 0.47 \\
\hline Smoking status, yes & $15(16.5)$ & $2(3.5)$ & $13(38.2)$ & $0.00 * *$ \\
\hline \multicolumn{5}{|l|}{ Meal routine } \\
\hline Breakfast, yes & $60(65.9)$ & $36(63.2)$ & $24(70.6)$ & 0.47 \\
\hline Lunch, yes & $80(87.9)$ & $48(84.2)$ & $32(94.1)$ & 0.16 \\
\hline Diner, yes & $65(71.4)$ & $37(64.9)$ & $28(82.4)$ & 0.08 \\
\hline Snack, yes & $44(48.4)$ & $31(54.4)$ & $13(38.2)$ & 0.14 \\
\hline \multicolumn{5}{|c|}{ Physical activity intensity } \\
\hline High, yes & $13(14.3)$ & $6(10.5)$ & $7(20.6)$ & 0.19 \\
\hline Intermediate, yes & 67 (73.6) & $41(71.9)$ & $26(76.5)$ & 0.63 \\
\hline Low, yes & $90(98.9)$ & $57(100)$ & $33(97.1)$ & 0.37 \\
\hline
\end{tabular}
HDL-c: High density lipoprotein cholesterol, LDL-c: Low density lipoprotein cholesterol

There was no significant difference in the proportion of 10-year ASCVD risk between genotypes in each SNP of PRKAA2 in this study $(p>0.05)$. Mostly, all of the genotypes of rs2796498, rs9803799, and rs2746342 had a low proportion of high-risk groups. However, it was found that only GT of rs9803799 had a higher proportion of high-risk ASCVD than other genotypes (Figure 1).

Associations between PRKAA2 genetic variation and 10-year ASCVD risk, both in bivariate analysis and in multivariate analysis, are listed in Table 2. Bivariate analysis failed to find any association between PRKAA2 genetic variation and 10-year ASCVD risk. After adjusting for sex, age, lipid profiles, physical activities high intensity, daily routine of lunch, dinner, and snack, using multivariate analysis, only rs 9803799 had a significant association with 10-year ASCVD risk. Patients with GT genotype had 187.86 times higher possibility for high-risk of 10-year ASCVD risk than TT genotype $(\mathrm{OR}=187.86,95 \% \mathrm{Cl}: 2.98-11863.51)$. 


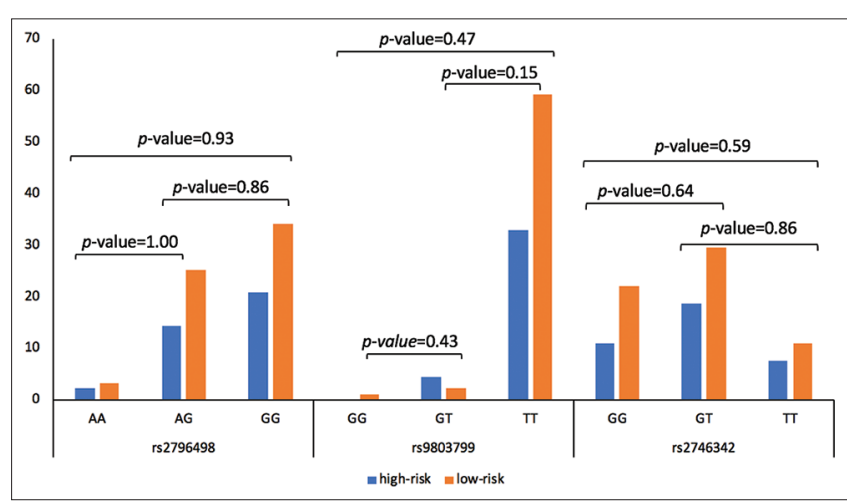

Figure 1: The 10-year ASCVD risk based on PRKAA2 genetic variation, in percentage

The dominant model also showed that GT+GG had 94.33 times higher possibility for high-risk 10-year

Table 2: The association between PRKAA2 genetic variation and 10-year ASCVD risk

\begin{tabular}{|c|c|c|c|c|c|c|c|}
\hline \multirow[t]{2}{*}{ SNP } & \multirow[t]{2}{*}{ Genotype } & \multicolumn{6}{|c|}{$\begin{array}{l}\text { Newly diagnosed T2DM patients using monotherapy } \\
\text { metformin }(n=91)\end{array}$} \\
\hline & & $\begin{array}{l}\text { high-risk } \\
(\mathrm{n}=34) \\
\mathrm{n}(\%)\end{array}$ & $\begin{array}{l}\text { low-risk } \\
(\mathrm{n}=57) \\
\mathrm{n}(\%)\end{array}$ & $\begin{array}{l}\text { OR } \\
(95 \% \mathrm{Cl})\end{array}$ & $p$-value & $\begin{array}{l}\mathrm{AOR}^{\mathrm{a}} \\
(95 \% \mathrm{Cl})\end{array}$ & $p$-value ${ }^{a}$ \\
\hline $\begin{array}{l}\text { PRKAA2 } \\
\text { rs2796498 }\end{array}$ & AA & $2(5.9)$ & $3(5.2)$ & $\begin{array}{l}1.09 \\
(0.17- \\
7.12)\end{array}$ & 0.93 & $\begin{array}{l}2.51 \\
(0.13- \\
47.96)\end{array}$ & 0.54 \\
\hline & $A G$ & $13(38.2)$ & $23(40.4)$ & $\begin{array}{l}0.92 \\
(0.38- \\
2.24)\end{array}$ & $1.00(\mathrm{re}$ & $\begin{array}{l}2.87 \\
(0.54- \\
15.20) \\
\text { eference) }\end{array}$ & 0.22 \\
\hline $\begin{array}{l}\text { Dominant } \\
\text { model }\end{array}$ & $A A+A G$ & $15(44.1)$ & $26(45.6)$ & $\begin{array}{l}0.94 \\
(0.40- \\
2.21)\end{array}$ & 0.89 & $\begin{array}{l}2.80 \\
(0.58- \\
13.62)\end{array}$ & 0.20 \\
\hline $\begin{array}{l}\text { Recessive } \\
\text { model }\end{array}$ & $\begin{array}{l}\text { GG } \\
\text { AA }\end{array}$ & $\begin{array}{l}19(55.9) \\
2(5.9)\end{array}$ & $\begin{array}{l}31(54.4) \\
3(5.3)\end{array}$ & $\begin{array}{l}1.13 \\
(0.18- \\
7.10)\end{array}$ & 0.90 & $\begin{array}{l}1.70(0.11 \\
-26.60)\end{array}$ & 0.71 \\
\hline $\begin{array}{l}\text { Allele } \\
\text { model }\end{array}$ & $\begin{array}{l}A G+G G \\
A \text { allele }\end{array}$ & $\begin{array}{l}32(94.1) \\
17(25.0)\end{array}$ & $\begin{array}{l}54(94.7) \\
29(25.4)\end{array}$ & $\begin{array}{l}0.98 \\
(0.49- \\
1.95)\end{array}$ & 0.95 & $\begin{array}{l}1.92 \\
(0.62- \\
5.94)\end{array}$ & 0.26 \\
\hline & G allele & $51(75.0)$ & 85 (74.6) & & & & \\
\hline $\begin{array}{l}\text { PRKAA2 } \\
\text { rs9803799 }\end{array}$ & $\begin{array}{l}\text { GG } \\
\text { GT }\end{array}$ & $\begin{array}{l}0(0) \\
4(11.8)\end{array}$ & $\begin{array}{l}1(1.8) \\
2(3.5)\end{array}$ & $\begin{array}{l}- \\
3.60 \\
(0.62- \\
20.82)\end{array}$ & $\overline{-} .15$ & $\begin{array}{l}- \\
187.86 \\
(2.98- \\
11863.51)\end{array}$ & $-\overline{0.013^{*}}$ \\
\hline $\begin{array}{l}\text { Dominant } \\
\text { model }\end{array}$ & $\mathrm{GG}+\mathrm{GT}$ & $4(11.8)$ & $3(5.3)$ & $\begin{array}{l}2.40 \\
(0.50- \\
11.45)\end{array}$ & 0.27 & $\begin{array}{l}94.33 \\
(2.32- \\
841.21)\end{array}$ & $0.016^{*}$ \\
\hline & TT & $30(88.2)$ & 54 (94.7) & & & & \\
\hline $\begin{array}{l}\text { Recessive } \\
\text { model }\end{array}$ & $\begin{array}{l}\text { GG } \\
\text { GT+TT }\end{array}$ & $\begin{array}{l}0(0) \\
34(100)\end{array}$ & $\begin{array}{l}1(1.8) \\
56(98.2)\end{array}$ & - & - & - & - \\
\hline $\begin{array}{l}\text { Allele } \\
\text { model }\end{array}$ & $\mathrm{G}$ allele & $4(5.9)$ & $4(3.5)$ & $\begin{array}{l}1.72 \\
(0.42- \\
7.11)\end{array}$ & 0.46 & $\begin{array}{l}20.48 \\
(1.48- \\
283.30)\end{array}$ & $0.024^{*}$ \\
\hline $\begin{array}{l}\text { PRKAA2 } \\
\text { rs2746342 }\end{array}$ & $\begin{array}{l}\text { T allele } \\
\text { TT }\end{array}$ & $\begin{array}{l}64(94.1) \\
7(20.6)\end{array}$ & $\begin{array}{l}110(96.5) \\
10(17.5)\end{array}$ & $\begin{array}{l}1.40 \\
(0.41- \\
4.78)\end{array}$ & 0.59 & $\begin{array}{l}3.69 \\
(0.23- \\
60.37)\end{array}$ & 0.36 \\
\hline & GT & $17(50.0)$ & $27(47.4)$ & $\begin{array}{l}1.26 \\
(0.48 \\
-3.33)\end{array}$ & $1.00 / \mathrm{r}$ & $\begin{array}{l}3.36 \\
(0.58 \\
-19.47) \\
\text { eference) }\end{array}$ & 0.18 \\
\hline $\begin{array}{l}\text { Dominant } \\
\text { model }\end{array}$ & $\mathrm{TT}+\mathrm{GT}$ & 24 (70.6) & 37 (64.9) & $\begin{array}{l}1.30 \\
(0.52- \\
3.24)\end{array}$ & 0.58 & $\begin{array}{l}3.41 \\
(0.62- \\
18.68)\end{array}$ & 0.16 \\
\hline & GG & $10(29.4)$ & $20(35.1)$ & & & & \\
\hline $\begin{array}{l}\text { Recessive } \\
\text { model }\end{array}$ & $\mathrm{TT}$ & $7(20.6)$ & $10(17.5)$ & $\begin{array}{l}1.22 \\
(0.42- \\
3.57)\end{array}$ & 0.72 & $\begin{array}{l}1.79 \\
(0.15- \\
21.27)\end{array}$ & 0.64 \\
\hline & $G G+G T$ & $27(79.4)$ & 47 (82.5) & & & & \\
\hline $\begin{array}{l}\text { Allele } \\
\text { model }\end{array}$ & G allele & $31(45.6)$ & $67(58.8)$ & $\begin{array}{l}1.19 \\
(0.65- \\
2.19)\end{array}$ & 0.57 & $\begin{array}{l}1.89 \\
(0.65- \\
5.47)\end{array}$ & 0.24 \\
\hline
\end{tabular}

ASCVD risk than the TT genotype $(\mathrm{OR}=94.33 ; 95 \% \mathrm{Cl}$ : 2.32-3841.21). Those findings indicated that the $G$ allele had 20.48 times higher possibility for high-risk 10-year ASCVD risk than the $\mathrm{T}$ allele $(\mathrm{OR}=20.48$; 95\% Cl: 1.48-283.30).

Remarkably, $A A$ as wildtype and the $A G$ genotype in rs2796498 showed higher odds of highrisk 10 -year ASCVD risk in the multivariate analysis than bivariate analysis. However, it did not become significant statistically ( $p>0.05$ ). Mutant genotype in rs2746342 contributed a higher odds to gain high-risk of 10-year ASCVD risk than wildtype genotype, but there was no significant association $(p>0.05)$, even after multivariate analysis.

\section{Discussion}

Our results emphasized the findings from a previous study in Sleman District which found that 10-year ASCVD risk among participants was categorized as low-risk. However, they used the Framingham risk score to measure ASCVD risk [25]. This study found that the group with high-risk of 10-year ASCVD risk had more older participants than the low-risk group. The findings of various studies have reported that age significantly contributed to ASCVD risk as an independent risk factor [26], [27]. Notably, the $\mathrm{HbA} 1 \mathrm{c}$ level was higher in the low-risk group than the high-risk group. The literature has discovered the relationship between $\mathrm{HbA} 1 \mathrm{c}$ level and ASCVD risk. Our finding was the opposite of studies stating that increasing $\mathrm{HbA} 1 \mathrm{c}$ level is a major risk factor of ASCVD outcomes [28], [29]. Our results align with the previous findings that females tend to have lower ASCVD risk, especially before menopause. Menopause could reduce the sex hormones that could affect ASCVD risk through changes in vasculature, cardiac muscle, metabolism, and coagulation [30], [31], [32]. Smoking is one of the substantial factors involved in escalating ASCVD events, and the risk is doubled [33]. Our results confirmed that report, where the proportion of smokers was higher in the high-risk group than the low-risk group.

The proportion of low-risk 10-year ASCVD risk was dominant in almost all genotypes, except GT of rs9803799. It seemed that both the heterozygote and the homozygote genotype, could have a role in affecting disease risk [34]. However, our findings could not explain any significant difference in ASCVD risk proportion between each genotype.

This present study investigated the association between three variants in the PRKAA2 gene, rs2796498, rs9803799, and rs2746342, with 10-year ASCVD risk in newly diagnosed T2DM patients who have been prescribed metformin for three months consecutively. Our 
findings indicated that only rs9803799 had an association with 10-year ASCVD risk. GT genotype and dominant model (GT+GG) had a significant association to have higher risk of 10-year ASCVD risk than TT genotype, whereas TT genotype is the mutant genotype of rs9803799. The result showed that those with the $G$ allele also have a higher chance of getting high-risk ASCVD than the $\mathrm{T}$ allele. In fact, there has not been a study that examines PRKAA2 genetic variation and 10-year ASCVD risk. SNP rs9803799 is located in a 3' prime UTR responsible for controlling transcription, initiating or inhibiting translation, and localizing in the cytoplasm [35]. Previous findings indicated that rs9803799 had a significant association with metformin efficacy [36]. In line with that study's results, the rs9803799 variant might have a pivotal role in AMPK expression; then, it could influence metformin efficacy and ASCVD risk. Undoubtedly, genetic variation could not stand alone to predict ASCVD risk. In this case, we could discover a significant association after adjusting for nongenetic factors in multivariate analysis. Several studies have confirmed that genetic and environmental factors interact and that interrelationship affects the development of ASCVD [37], [38], [39].

Furthermore, a study in Caucasian populations reported that rs2796498 and rs2746342 were associated with lipid profiles. SNP rs2796498 impacted HDL-C, LDL-C, and total cholesterol, while rs2746342 affected LDL-c and total cholesterol [40]. Lipid profiles are the dominant factor which have considerable weight in the 10-year ASCVD risk calculation. Nevertheless, this study could not identify any significant association between rs2796498 and rs2746342 and ASCVD risk.

Review literature declared that PRKAA2, which affected the metformin effectiveness, impacted ASCVD risk [41], [42]. A study applying the Mendelian randomization model which used AMPK as metformin pharmacologic target reported that there was genetic evidence in AMPK variance that could provide ASCVD protection [43].

Theoretically, AMPK has a crucial role in the metformin mechanism for reducing ASCVD risk. Metformin can activate AMPK, either by way of the direct pathway or indirect pathway, by inhibiting mitochondrial respiratory chain complex, thus altering AMP/ATP level [44], [45]. Several molecular studies investigating the pleiotropic effect of metformin mediated by AMPK proclaimed that AMPK and metformin could reduce ASCVD risk through the various pathways. Those explanations involved: (1) increasing fatty acid oxidation through acetyl-CoA carboxylase activation, (2) enhancing glucose uptake over GLUT4 induction, thus increase catabolism, (3) elevating endothelial nitric acid synthase (eNOS) level as a consequence, it decreases reactive oxygen species and increases endothelial function, (4) activating PGC-1a who supports left ventricle function, (5) inhibiting sterol regulatory elementbinding protein 2 (SREBP-2) maturation for low-density lipoprotein receptor (LDLR) binding, (6) suppressing Toll-like receptor 4 (TLR4) thus inhibiting the inflammatory mediator, and (7) inhibiting apoptosis through platelet-derived growth factor receptor (PDGFR) suppression [46], [47], [48], [49], [50].

This present study has several limitations. First, lipid profiles that contribute to 10-year ASCVD risk calculation were only examined after metformin therapy was initiated. Second, we only detected diet aspects from a daily meal routine, whereas diet significantly impacts ASCVD. Third, we only found one participant who had GG genotype of rs9803799. Finally, though the participants were selected from a representative sample of patients with newly diagnosed T2DM who have been prescribed only metformin, the results would be more convincing in a bigger sample size.

\section{Conclusions}

In summary, our finding confirmed that PRKAA2 genetic variation might impact the 10-year ASCVD risk among newly diagnosed T2DM patients receiving monotherapy metformin, especially in the rs9803799. Patient assessment should consider the combination of genetic and environmental factors to determine 10-year ASCVD risk.

\section{Acknowledgments}

We thank all the participants for their participation and the engaged health practitioners in primary health care in Sleman Districts. The authors thank Prof. Iwan Dwiprahasto, M.Med.Sc., Ph.D. for supporting the study in the beginning. This study was supported by the Indonesia Endowment Fund for Education (LPDP) number: 201812220413569 and Rekognisi Tugas Akhir grant number: RTA 2488/ UN1.P.III/DIT-LIT/PT/2020.

\section{References}

1. Hardie DG, Ross FA, Hawley SA. AMPK-a nutrient and energy sensor that maintains energy homeostasis. Nat Rev Mol Cell Biol. 2012;13(4):251-62. https://doi.org/10.1038/nrm3311 PMid:22436748

2. Kim J, Yang G, Kim Y, Kim J, Ha J. AMPK activators Mechanisms of action and physiological activities. Exp Mol Med. 2016;48(4):e224-36. https://doi.org/10.1038/emm.2016.16

3. Meng S, Cao J, He Q, Xiong L, Chang E, Radovick S, 
et al. Metformin activates AMP-activated protein kinase by promoting formation of the $\alpha \beta \gamma$ heterotrimeric complex. J Biol Chem. 2015;290(6):3393-802. https://doi.org/10.1074/jbc. $\mathrm{m} 114.604421$

PMid:25538235

4. Viollet B, Andreelli F, Jørgensen SB, Perrin C, Flamez D, $\mathrm{Mu} \mathrm{J}$, et al. Physiological role of AMP-activated protein kinase (AMPK): Insights from knockout mouse models. Biochem Soc Trans. 2003;31(1):216-9. https://doi.org/10.1042/bst0310216 PMid: 12546688

5. Musi N, Hirshman MF, Nygren J, Svanfeldt M, Bavenholm P, Rooyackers $\mathrm{O}$, et al. Metformin increases AMP-activated protein kinase activity in skeletal muscle of subjects with Type 2 diabetes. Diabetes. 2002;51(7):2074-81. https://doi. org/10.2337/diabetes.51.7.2074

\section{PMid:12086935}

6. Musi N, Hayashi T, Fujii N, Hirshman MF, Witters LA, Goodyear LJ AMP-activated protein kinase activity and glucose uptake in rat skeletal muscle. Am J Physiol Metab. 2001;280(5):E677-84 https://doi.org/10.1152/ajpendo.2001.280.5.e677

PMid:11287349

7. Duan Q, Song P, Ding Y, Zhou M. Activation of AMP-activated protein kinase by metformin ablates angiotensin II-induced endoplasmic reticulum stress and hypertension in mice in vivo. Br J Pharmacol. 2017;174(13):2140-51. https://doi.org/10.1111/ bph.13833

PMid:28436023

8. Xu X, Lu Z, Fassett J, Zhang P, Hu X, Liu X, et al. Metformin protects against systolic overload-induced heart failure independent of AMP-activated protein kinase $\alpha 2$. Hypertension. 2014;63(4):723-8. https://doi.org/10.1161/ hypertensionaha. 113.02619 PMid:24420540

9. American Diabetes Association. Standards of medical care in diabetes. J Clin Appl Res Educ. 2020;43:1-212.

10. Bertoluci MC, Rocha VZ. Cardiovascular risk assessment in patients with diabetes. Diabetol Metab Syndr. 2017;9:25. https:// doi.org/10.1186/s13098-017-0225-1

\section{PMid:28435446}

11. Tancredi M, Rosengren A, Svensson AM, Kosiborod M, PivodicA Gudbjornsdottir S, et al. Excess mortality among persons with Type 2 diabetes. N Engl J Med. 2015;373(18):1720-32. https:// doi.org/10.1056/nejmoa1504347

PMid:26510021

12. Sia HK, Kor CT, Tu ST, Liao PY, Chang YC. Predictors of treatment failure during the first year in newly diagnosed Type 2 diabetes patients: A retrospective, observational study. PeerJ. 2021;9:e11005. https://doi.org/10.7717/peerj.11005 PMid:33717708

13. Rodriguez-Araujo G, Nakagami H. Pathophysiology of cardiovascular disease in diabetes mellitus. Cardiovasc Endocrinol Metab. 2018;7(1):4-9.

PMid:31646271

14. Hegab Z, Gibbons S, Neyses L, Mamas MA. Role of advanced glycation end products in cardiovascular disease. World $\mathrm{J}$ Cardiol. 2012;4(4):90-102. https://doi.org/10.4330/wjc.v4.i4.90 PMid:22558488

15. Jia G, DeMarco VG, Sowers JR. Insulin resistance and hyperinsulinaemia in diabetic cardiomyopathy. Nat Rev Endocrinol. 2016;12(3):144-53. https://doi.org/10.1038/ nrendo.2015.216 PMid:26678809

16. Haas AV, McDonnell ME. Pathogenesis of cardiovascular disease in diabetes. Endocrinol Metab Clin North Am.
2018;47(1):51-63.

PMid:29407056

17. Topel ML, Shen J, Morris AA, Mheid AA, Sher S, Dunbar SB, et al. Comparisons of the framingham and pooled cohort equation risk scores for detecting subclinical vascular disease in blacks versus whites. Am J Cardiol. 2018;121:564-9. https:// doi.org/10.1016/j.amjcard.2017.11.031

PMid:29361288

18. Dwivani C, Harijadi K, Suhadi R. Perbandingan lima metode estimasi risiko 10 tahun penyakit kardiovaskuler pada masyarakat kabupaten sleman-Yogyakarta. J Manage Pharm Pract. 2018;8:59-69.

19. Cosentino F, Grant PJ, Aboyans V, Bailey CJ, Ceriello A Delgado V, et al. 2019 ESC guidelines on diabetes, pre-diabetes, and cardiovascular diseases developed in collaboration with the EASD. Eur Heart J. 2020;41(2):255-323. https://doi. org/10.1093/eurheartj/ehz687

PMid:31497854

20. Nguyen NC, Pham HT, Pham DT, Hoang TM, Dam TP, Ho TH, et al. Comparison of 3 medicine groups used to control glycemic and glycated hemoglobin levels in newly diagnosed Type 2 diabetes patients. Open Access Maced J Med Sci. 2021;9:101-6. https://doi.org/10.3889/oamjms.2021.4672

21. Griffin SJ, Leaver JK, Irving GJ. Impact of metformin on cardiovascular disease: A meta-analysis of randomised trials among people with Type 2 diabetes. Diabetologia. 2017;60(9):1620-29. https://doi.org/10.1007/ s00125-017-4337-9

PMid:28770324

22. Batchuluun B, Sonoda N, Takayanagi R. The cardiovascular effects of metformin: Conventional and new insights antidiabetic drug-metformin. J Endocrinol Diabetes Obes. 2014;2:1035.

23. Florez JC. The pharmacogenetics of metformin. Diabetologia. 2017;60(9):1648-55.

PMid:28770331

24. Lloyd-Jones DM, Braun LT, Ndumele CE, Smith SC Jr., Sperling LS, Virani SS, et al. Use of risk assessment tools to guide decision-making in the primary prevention of atherosclerotic cardiovascular disease: A special report from the American heart association and American college of cardiology. J Am Coll Cardiol. 2019;73(24):3153-67. https://doi. org/10.1016/j.jacc.2018.11.005

PMid:30423392

25. Suhadi R, Virginia DM, Setiawan $\mathrm{CH}$. Association of lipid profiles with 10-year atherosclerotic cardiovascular disease risk: Study among subjects in sleman district of yogyakarta Indonesia. Asian J Pharm Clin Res. 2017;10:166-70. https://doi. org/10.22159/ajpcr.2017.v10i12.20675

26. Dhingra R, Vasan RS. Age as a risk factor. Med Clin North Am. 2012;96(1):87-91. https://doi.org/10.1016/j.mcna.2011.11.003 PMid:22391253

27. Maharani A, Sujarwoto, Praveen D, Oceandy D, Tampubolon G Patel A, et al. Cardiovascular disease risk factor prevalence and estimated 10-year cardiovascular risk scores in Indonesia: The SMARThealth extend study. PLoS One. 2019;14:e0215219. https://doi.org/10.1371/journal.pone.0215219 PMid:31039155

28. Cavero-Redondo I, Peleteiro B, Álvarez-Bueno C, RodriguezArtalejo F, Martinez-Vizcaino V. Glycated haemoglobin A1C as a risk factor of cardiovascular outcomes and all-cause mortality in diabetic and non-diabetic populations: A systematic review and meta-analysis. BMJ Open. 2017;7(7):e015949. https://doi. org/10.1136/bmjopen-2017-015949

PMid:28760792

29. TODAY Study Group, Zeitler P, Hirst K, Pyle L, Linder B, 
Copeland $\mathrm{K}$, McKay $\mathrm{S}$, et al. A clinical trial to maintain glycemic control in youth with Type 2 diabetes. N Engl J Med. 2012;366(24):2247-56. https://doi.org/10.1056/nejmoa1109333 PMid:22540912

30. Harvey RE, Coffman KE, Miller VM. Women-specific factors to consider in risk, diagnosis and treatment of cardiovascular disease. Womens Health. 2015;11(2):239-57. https://doi. org/10.2217/whe.14.64

PMid:25776297

31. Norris CM, Yip CY, Nerenberg KA, Clavel MA, Pacheco C, Foulds HJ, et al. State of the science in women's cardiovascular disease: A Canadian perspective on the influence of sex and gender. J Am Heart Assoc. 2020;9(4):e015634 PMid:32063119

32. Banks E, Welsh J, Joshy G, Martin M, Paige E, Korda RJ. Comparison of cardiovascular disease risk factors, assessment and management in men and women, including consideration of absolute risk: A nationally representative cross-sectional study. BMJ Open. 2020;10:e038761. https://doi.org/10.1136/ bmjopen-2020-038761

33. Banks E, Joshy G, Korda RJ, Stavreski B, Soga K, Egger S, et al. Tobacco smoking and risk of 36 cardiovascular disease subtypes: Fatal and non-fatal outcomes in a large prospective Australian study. BMC Med. 2019;17(1):128. https://doi. org/10.1186/s12916-019-1351-4 PMid:31266500

34. Xu K, Kosoy R, Shameer K, Kumar S, Liu L, Readhead B, et al. Genome-wide analysis indicates association between heterozygote advantage and healthy aging in humans. BMC Genet. 2019;20:1-14. https://doi.org/10.1186/ s12863-019-0758-4

35. Maodobra M. The role of single nucleotide polymorphisms of untranslated regions (Utrs) in insulin resistance pathogenesis in patients with Type 2 diabetes. In: Medical Complications of Type 2 Diabetes. India: InTech; 2011. https://doi.org/10.5772/23348

36. Jablonski KA, McAteer JB, De Bakker PI, Franks PW, Pollin TI, Hanson RL, et al. Common variants in 40 genes assessed for diabetes incidence and response to metformin and lifestyle intervention in the diabetes prevention program. Diabetes. 2010;59(10):2672-81. https://doi.org/10.2337/db10-0543 PMid:20682687

37. Norrington K, Androulakis E, Christophides T. Interactionsinterrelationships between genetics and environmental factors in cardiovascular disease. In: Cardiovascular Diseases: Genetic Susceptibility, Environmental Factors and their Interaction. Netherlands: Elsevier Inc.; 2016. p. 219-30. https://doi. org/10.1016/b978-0-12-803312-8.00010-0

38. Ji F, Ning F, Duan H, Kaprio J, Zhang D, Zhang D, et al. Genetic and environmental influences on cardiovascular disease risk factors: A study of Chinese twin children and adolescents. Twin Res Hum Genet. 2014;17(2):72-9. https://doi.org/10.1017/ thg.2014.5

PMid:24576535

39. Jermendy G, Horváth T, Littvay L, Steinbach R, Jermendy AL, Tarnoki AD, et al. Effect of genetic and environmental influences on cardiometabolic risk factors: A twin study. Cardiovasc Diabetol. 2011;10:96. https://doi.org/10.1186/1475-2840-10-96 PMid:22050728

40. Spencer-Jones NJ, Ge D, Snieder H, Perks U, Swaminathan R, Spector TD, et al. AMP-kinase alpha2 subunit gene PRKAA2 variants are associated with total cholesterol, low-density lipoprotein-cholesterol and high-density lipoprotein-cholesterol in normal women. J Med Genet. 2006;43(12):936-42. https:// doi.org/10.1136/jmg.2006.041988

PMid:16801347

41. Åkerborg Ö, Spalinskas R, Pradhananga S, Anil A, Hojer $P$, Poujade FA, et al. High-resolution regulatory maps connect cardiovascular risk variants to disease related pathways. Circ Genom Precis Med. 2019;12(3):e002353. https://doi org/10.1101/376699

PMid:30786239

42. Randrianarisoa E, Lehn-Stefan A, Krier J, Bohm A, Heni M, Angelis $\mathrm{MH}$, et al. AMPK subunits harbor largely nonoverlapping genetic determinants for body fat mass, glucose metabolism, and cholesterol metabolism. J Clin Endocrinol Metab. 2020;105:dgz020. https://doi.org/10.1210/clinem/dgz020 PMid:31512724

43. Luo S, Schooling CM, Wong IC, Yeung SL. Evaluating the impact ofAMPK activation, a target of metformin, on risk of cardiovascular diseases and cancer in the UK Biobank: A Mendelian randomisation study. Diabetologia. 2020;63(11):2349-58. https://doi.org/10.1007/s00125-020-05243-z

PMid:32748028

44. Wang Y, An H, Liu T, Qin C, Sesaki H, Guo S, et al. Metformin improves mitochondrial respiratory activity through activation of AMPK. Cell Rep. 2019;29(6):1511-23.e5. https://doi. org/10.1016/j.celrep.2019.09.070

PMid:31693892

45. Agius L, Ford BE, Chachra SS. The metformin mechanism on gluconeogenesis and AMPK activation: The metabolite perspective. Int J Mol Sci. 2020;21(9):3240. https://doi. org/10.3390/ijms21093240

PMid:32375255

46. Xie Z, Lau K, Eby B, Lozano P, He C, Pennington B, et al. Improvement of cardiac functions by chronic metformin treatment is associated with enhanced cardiac autophagy in diabetic OVE26 mice. Diabetes. 2011;60(6):1770-78. https:// doi.org/10.2337/db10-0351

PMid:21562078

47. Kobashigawa LC, Xu YC, Padbury JF, Tseng YT, Yano N Metformin protects cardiomyocyte from doxorubicin induced cytotoxicity through an AMP-activated protein kinase dependent signaling pathway: An in vitro study. PLoS One. 2014;9(8):e104888. https://doi.org/10.1371/journal. pone. 0104888

PMid:25127116

48. Soraya H, Clanachan AS, Rameshrad M, Maleki-Dizaji N, Ghazo-Khansari M, Garjani A. Chronic treatment with metformin suppresses toll-like receptor 4 signaling and attenuates left ventricular dysfunction following myocardial infarction. Eur J Pharmacol. 2014;737:77-84. https://doi.org/10.1016/j. ejphar.2014.05.003

PMid:24842192

49. Gopoju R, Panangipalli S, Kotamraju S. Metformin treatment prevents SREBP2-mediated cholesterol uptake and improves lipid homeostasis during oxidative stress-induced atherosclerosis. Free Radic Biol Med. 2018;118:85-97. https:// doi.org/10.1016/j.freeradbiomed.2018.02.031 PMid:29499335

50. Lu Q, Li X, Liu J, Sun X, Rousselle T, Ren D, et al. AMPK is associated with the beneficial effects of antidiabetic agents on cardiovascular diseases. Biosci Rep. 2019;39(2):BSR20181995. https://doi.org/10.1042/bsr20181995

PMid:30710062 